\title{
Kesiapan Sekolah dalam Penerapan Kearsipan Berbasis Digital
}

\section{Sri Yeyenri Putrianti Hau', Ikhfan Haris², Mohammad Polinggapo ${ }^{3}$}

Jurusan Manajemen Pendidikan Fakultas Ilmu Pendidikan

Universitas Negeri Gorontalo

E-mail: Sriyeyenrihau24@gmail.com

\section{INFO ARTIKEL}

SejarahArtikel:

Diterima:Januari 2020

Disetujui:Februari 2020

Dipublikasi:Maret 2020

\section{Kata kunci:}

Kesiapan; penerapan;

kearsipan;

berbasisdigital

Keywords:

Readiness; application; archiving; digital based

\begin{abstract}
ABSTRAK
Penelitian ini bertujuan untuk mengetahui :1) kebijakan sekolah mengenai penerapan kearsipan berbasis digital, 2) prosedur penerapan kearsipan berbasis digital, 3) kesiapan sumber daya manusia dalam penerapan kearsipan berbasis digital,4) kesiapan sarana dan prasarana dalam penerapan kearsipan berbasis digital , 5) pendanaan dalam penerpan kearsipan berbasis digital. Metode yang digunakan adalah kuantitatif jenis deskriptif eksplanatori. Teknik pengumpulan data menggunakan angket, observasi, wawancara dan dokumentasi.Hasil penelitian menunjukkan bahwa : 1) kebijakan sekolah berada pada kategori siap, 2) prosedur penerapan berada pada kategori siap, 3) kesiapan sumber daya manusia berada pada kategori siap, 4) kesiapan sarana dan prasarana berada pada kategori siap, 5) pendanaan berada pada kategori kurang siap. Analisis Kesiapan Sekolah dalam Penerapan Kearsipan Berbasis Digital di SMK Negeri 4 Gorontalo berada pada kategori siap, sehingga perlu untuk ditingkatkan dan dipertahankan.
\end{abstract}

\begin{abstract}
This study aims to determine: 1) school policies regarding the application of digital-based archiving, 2) procedures for applying digital-based archiving, 3) readiness of human resources in the application of digital-based archiving, 4) readiness of facilities and infrastructure in the application of digital-based archiving, 5) funding in digital based archiving. The method used is quantitative descriptive explanatory type. Data collection techniques using questionnaires, observation, interviews and documentation. The results showed that: 1) school policies were in the ready category, 2) implementation procedures were in the ready category, 3) human resource readiness was in the ready category, 4) facility and infrastructure readiness was in the ready category, 5) funding was in the category not quite ready. School Readiness Analysis in the Application of Digital-Based Archiving in SMK Negeri 4 Gorontalo is in the ready category, so it needs to be improved and maintained.
\end{abstract}

(C) 2020 Sri Yeyenri Putrianti Hau, Ikhfan Haris, Mohammad Polinggapo Under The License CC BY-SA 4.0

\section{PENDAHULUAN}

Perkembangan ilmu dan teknologi menuntut unit kearsipan sebagai unit informasi untuk menerapkan sistem kearsipan yang disesuaikan dengan kemajuan teknologi informasi. Mengingat bahwa informasi dalam arsip merupakan informasi yang penting, maka untuk 
memenuhi kebutuhan pengguna akan informasi yang relevan dan dalam pelaksanaan tugas organisasi perlu didukung fasilitas penemuan kembali arsip yang cepat dantepat.Banyaknya pekerjaan yang berkaitan dengan arsip dan dokumen dihadapkan pada pengelolaan arsip secara konvensional menjadi awal munculnya titik terang ke arah pembuatan sebuah sistem yang mampu mengurangi beban kerja petugas kearsipan atau arsiparis dalam pengelolaan kearsipan. Sistem tersebut merupakan sistem kearsipan konvensional yang diaplikasikandalam bentuk software dengan mengunakam media elektronik yang berbasiskan pada penggunaan komputer atau dapat dikatakan sebgai sistem kearsipan digital.

Menurut (Syagala, 2008:97) kebijakan diartikan sebagai kepandaian, kemahiran kebijaksanaan, rangkaian konsep dan asas yang menjadi garis dasar dan dasar rencana dalam pelaksanaan pekerjaan, kepemimpinan dan cara bertindak oleh pemerintah, organisasi dan sebagainya sebagai pernyataan cita-cita prinsip atau maksud sebagai garis pedoman untuk manajemen dalam mencari sasaran.Odgers dalam (Sukoco, 2007:83) kearsipan adalah manajemen arsip sebgai proses pengawasan, penyimpanan, dan pengamanan dokumen serta arsip baik dalam bentuk kertas maupun media elektronik.Sedangkan Menurut (Wursanto, 1991:12), Kearsipan adalah proses kegiatan penggunaan atau pengaturan arsip dengan mempergunakan suatu sistem tertentu sehimgga arsip-arsip dapat ditemukan dengan mudah dan cepat apabila sewaktu-waktu diperlukan.Data-data yang dapat diolah dalam bentuk digital dapat berupa gambar, suara, video, tulisan, atau data lainnya yang dapat dijadikan sebagai sebuah dalam bentuk biner, sehingga dapat diolah dalam program komputasi dan disimpan dalam penyimpanan digital (Muhidin dkk, 2016).

Media yang dapat menyimpan data digital memiliki bentuk yang berbeda dengan fisik arsip aslinya. Media tersebut tidak dapat dibaca secara langsung tanpa menggunakan alat bantu pembaca media digital, seperti komputer atau lainnya. Media pembaca data digital yang saat ini popular antara lain: Hard Disk Driver (HDD), kartu penyimpanan, atau bentuk lainnya. Sementara media penyimpanan digital yang sekarang umum digunakan adalah menggunakan harddisk, karena memiliki kapasitas yang besar, hingga relaif murah, daya tahan yang cukup baik, dan dapat diintegrasikan ke dalam system server komputer (Muhidin dkk, 2016).

Tahapan yang dapat dilakukan dalam kegiatan penyimpanan arsip digital, khususnya yang terkait alih media arsip dari media kertas ke media elekteonik/komputer adalah (Muhidin danHendri,2016:412):1)Menyiapkan surat/naskah dinas yang akan di alih media, 2) Melakukan scanning terhadap naskah, surat ataudokumenlain, 3) Membuat foder-folder 
pada komputer sebagai tempat penyimpanan surat, naskah atau dokumen yang telah di scan. 4) Membuat hyperlink yaitu penghubung antar daftar arsip dengan arsip hasil scan, 5) Membuat kelengkapan administrasi alih media, yang terdiri dari:(a)suratkeputusantimalihmedia, (b) berita acara persetujuan alihmedia, (c) beritaacaralegalisasialihmedia,(d) daftar arsip usul alih media, dan (e) daftar alihmedia. (Ismail dan Jamaludin, 2009:134-146) menyatakan bahwa bukan hanya infrastruktur semata yang membutuhkan fokus dalam pengembangan pengelolaan arsip elektronikdieradigital,melainkanjuga faktormanusia.Keberhasilan serta kelancaran dalam kegiatan alih media arsip pasti memerlukan sarana dan prasaranayang handal dan sesuai standar kearsipan. Adapun sarana dan prasarana yang dibutuhkan antara lain: penyediaan ruang, peralatan, perangkat lunak, kualifikasi arsip dan kualifikasisumber daya manusia (Effendhie, 2010).

Pelaksanaan manajemen kearsipan yang baik, mutlakdiperlukan oleh lembaga pendidikan, karena kegiatan kearsipan mencakup proses penyusunan dan penyimpanan suratsurat atau dokumen mulai dari sekolah itu didirikan, pencatatan dan penerimaansiswabarusampaisiswaitu keluar atau lulus, maupun pencatatan seluruh data personel tenaga pendidik dan kependidikan di sekolah itu. Oleh karena itu manajemenkearsipanmenjadi hal yang sangat penting dan menjadi keharusan untuk terus ditingkatkan dalam pelayanannya.

Berdasarkan latar belakang di atas maka permasalahan dalam penelitian ini diorientasikan sepenuhnya pada batasan sebagai berikut: 1) Bagaimana kebijakan sekolah mengenai penerapan kearsipan berbasis digital di SMK Negeri 4 Gorontalo ? 2) Bagaimana prosedur penerapan kearsipan berbasis digital di SMK Negeri 4 Gorontalo ? 3) Bagaimana kesiapan sumber daya manusia dalam penerapan kearsipan berbasis digital di SMK Negeri 4 Gorontalo ? 4) Bagaimana kesiapan sarana dan prasarana dalam penerapan kearsipan berbasis digital di SMK Negeri 4 Gorontalo ? 5) Pendanaan dalam penerapan kearsipan berbasis digital di SMK Negeri 4 Gorontalo ?

\section{METODE PENELITIAN}

Penelitian ini dilaksanakan di SMK Negeri 4 Gorontalo, metodeyang yang digunakan dalam metode ini adalah metode kuantitatif jenis deskriptif eksplanatori, yang bertujuan untuk memperoleh informasi serta gambaran data mengenai objek yang diteliti melalui data subyek sebagaimana adanya, tanpa melakukan analisis dan membuat kesimpulan yang berlaku untukumum. Indikator pada penelitian ini yaitu, 1) kebijakan 
sekolah, 2)prosedur penerapan, 3) kesiapan sumber daya manusia, 4) kesiapan sarana dan prasarana, 5)pendanaan.Populasi adalah keseluruhan subjek penelitian (Arikunto,2006:108). Dalam hal ini subjek adalah populasi. Subjek populasinya adalah tenaga pendidik dan tenaga kependidikan. Adapun jumlah anggota subjek dalam penelitian ini adalah 51 orang. Instrumen penelitian yang digunakan dalam penelitian ini adalah anggket, wawancara, observasidan dokumentasi. Untuk penelitian ini data yang diperoleh dari responden akan dianalisis dengan menggunakan analisis deskriptif dalam bentuk tabel frekuensi dengan formula (Sugiyono, 2002:107).

\section{HASIL PENELITIAN}

Variabel dalam penelitian ini yaitu : analisis kesiapan sekolah dalam penerapan kearsipan berbasis digital.Dari hasil penelitian ini berbentuk skor persentase yang diperoleh dari data penyebaran angket kepada 51 responden dengan menjawab 40 pernyataan yang disajikan melalui hasil persentase yaitu Rangkuman skor keseluruhan indikator sebagai berikut:

1. Kebijakan Sekolah

Indikator kebijakan sekolah mengenai penerapan kearsipan berbasis digital di SMK Negeri 4 Gorontalo dengan rata-rata skor 211.375,persentase 82.88, berada pada kriteria siap.

2. Prosedur Penerapan

Indikator mengenai prosedur penerapan kearsipan berbasis digital di SMK Negeri 4 Gorontalo dengan rata- rata skor 217.4, persentase 85.25 , berada pada kriteria siap.

3. Kesiapan Sumber Daya Manusia

Indikator mengenai kesiapan sumber daya manusia dalam penerapan kearsipan berbasis digital di SMK Negeri 4 Gorontalo dengan rata-rata skor 216.63, persentase 84.95, berada pada kriteria siap.

4. Kesiapan Sarana dan Prasarana

Indikator mengenai kesiapan sarana dan prasarana dalam penerapan kearsipan berbasis digital di SMK Negeri 4 Gorontalo dengan rata-rata skor 213.36, persentase 83.66, berada pada kriteria siap.

5. Pendanaan

Indikator mengenai pendanaan dalam penerapan kearsipan berbasis digital di SMK Negeri 4 Gorontalo dengan rata-rata skor 191.6 persentase 75.13 , pada kategori kurang siap. 


\section{PEMBAHASAN}

Berdasarkan rekapitulasi hasil penelitian Analisis Kesiapan Sekolah dalam Penerapan Kearsipan Berbasis Digital di SMK Negeri 4 Gorontalo, kebijakan sekolah memiliki persentase $82.88 \%$ berada pada kategori siap, prosedur penerapan memiliki persentase $85.25 \%$ berada pada kategori siap, kesiapan sumber daya manusia memiliki persentase 84.95\% berada pada kategori siap, kesiapan sarana dan prasarana memiliki persentase $83.81 \%$ berada pada kategori siap dan pendanaan memiliki persentase $75.13 \%$ berada pada kategori kurang siap.

1. Kebijakan Sekolah

Kebijakan sekolah dalam konteks ini adalah berorientasi pada rencana penerapan kearsipan berbasis digital. Indikator mengenai hal ini berada pada kategori siap dengan nilai persentase yang diperoleh yaitu $82.88 \%$. hal ini karena sekolah sekolah memiliki rencana penerapan kearsipan berbasis digital. Sebagaimana yang dijelaskan (Syagala, 2008:97), mengemukakan bahwa kebijakan diartikan sebagai kepandaian, kemahiran, kebijaksanaan, rangkaian konsep dan asas yang menjadi garis dasar dan dasar rencana dalam pelaksanaan pekerjaan, kepemimpinan dan cara bertindak oleh pemerintah, organisasi dan sebagainya sebagai pernyataan cita-cita prinsip atau maksud sebagai garis pedoman untuk manajemen dalam mencapai sasaran. Empat varaibel atau faktor yang berpengaruh tehadap keberhasilan atau kegagalan implementasi kebijakan yaitu : 1) faktor komunikasi (communication), 2) sumber daya (resources), 3) disposisis (disposition), dan 4) Sruktur birokrasi (bureaucratic structure) (Widodo, 3013:96).Implementasi kebijakan merupakan salah satu komponen dalam proses kebijakan. Melaksanakan kebijakan berarti melaksanakan pilihan yang telah di tetapkan dari berbagai alternantif dalam perumusan dan perundangan yang berlaku, didukung oleh personil yang profesional, serta sarana dan prasarana yang tersedia.

Hasil penelitian di SMK Negeri4 Gorontalo menunjukan bahwa kebijakan sekolah mengenai penerapan kearsipan berbasis digital ada sejak tahun 2014. kepala sekolah melalui rapat staf dewan guru dan pegawai tata usaha bahwa sekolah sepakat untuk melaksanakan sistem pengarsipan dokumen secara digital.

\section{Prosedur Penerapan}

Prosedur penerapan dalam konteks ini adalah berorientasi pada mekanisme kerja penerapan kearsipan berbasis digital. Indikator mengenai hal ini berada pada kategori siap dengan nilai persentase yang diperoleh yaitu 85.25\%. Dalam prosedurnya sekolah menyiapkan arsip manual yang akan dialihmedia menjadi arsip digital. Berikut adalah tahapan yang dapat dilakukan dalam kegiatan penyimpanan arsip digital, khususnya yang 
terkait alih media arsip dari media kertas ke media elekteonik/komputer adalah (Muhidin dan Hendri, 2016: 412): 1) Menyiapkan surat/naskah dinas yang akan di alih media, 2) Melakukan scanning terhadap naskah, surat atau dokumen lain, 3) Membuat foder-folder pada komputer, sebagai tempat penyimpanan surat, naskah atau dokumen yang telah di scan. 4)Membuat hyperlink yaitu penghubung antar daftar arsip dengan arsip hasil scan, 5) Membuat kelengkapan administrasi alih media. Tujuan alih media arsip untuk mempercepat layanan akses arsip, dilakukan terkait tujuan pengelolaan arsip yang efektif dan efisien (Muhidin dan Hendri 2016:411).

Hasil penelitian di SMK Negeri4 Gorontalo mengenai prosedur penerapan kearsipan berbasis digital, sekolah menyiapkan dokumen- dokemen seperti data-data guru dan pegawai yang merupakan arsip manual kemudian alihmedia menjadi arsip digital dengan mengunakan scanner.

3. Kesiapan Sumber Daya Manusia

Kesiapan sumber daya manusia adalah kesiapan yang berorientasi pada sumber daya manusia sebagai penggerak dalam penerapan kearsipan berbasis digital. Indikator mengenai hal ini berada pada kategori siap dengan nilai persentase yang diperoleh yaitu $84.95 \%$. hal ini sumber daya manusia di SMK Negeri 4 Gorontalo dalam penerapan kearsipan secara digital memiliki SDM yang cukup baik itu dari tenaga pendidik dan tenaga kependidikan yang menguasai teknologi informasi yang mampu mengoperasikan komputer dengan baik. (Ismail dan Jamaludin, 2009:134-146) menyatakan bahwa bukan hanya infrastruktur semata yang membutuhkan fokus dalam pengembangan pengelolaan arsip elektronik di era digital, melainkan juga faktor manusia. Menurut Widodo (3013:96) sumberdaya adalah indikatordan titik sentral terlaksana tidaknya implementasi kebijakan sebab apabila implementator kekuarangan sumber daya maka sesuatu yang akan di implementasikan tidak akan berjalan efisien dan efektif, sumberdaya dapat berupa manusia, sarana, dan anggaran.

Hasil penelitian di SMK Negeri4 Gorontalo menunjukan bahwa dalam penerapan kearsipan berbasis digital mengenai kesiapan sumber daya manusia sekolah siap. SMK Negeri 4 Gorontalo dalam penerapan kearsipan secara digital memiliki SDM yang cukup, baik itu dari tenaga pendidik dan tenaga kependidikan yang menguasai teknologi informasi yang mampu mengoperasikan komputer dengan baik.

4. Kesiapan Sarana dan Prasarana

Kesiapan sarana dan prasarana adalah tingkat kemampuan sekolah dalam meneyediakan fasilitas dalam penerapan kearsipan berbasis digital. Indikator mengenai hal ini berada pada kategori siap dengan nilai persentase yang diperoleh yaitu $83.81 \%$. hal ini 
sarana dan prasarana yang disiapkan sekolah untuk pengarsipan berbasis digital sudah sesuai standar yang spesifikasinya sudah disesuaikan. Menurut KBBI (2002:999) Sarana adalah segala sesuatu yang dapat dipakai sebagai alat atau media dalam mencapai maksud dan tujuan. Jadi, kesiapan sarana adalah kesediaan alat atau media atau suatu kondisi dimana alat atau media itu siap berbuat sesuatu atau memberi respon. Sedangkan prasarana secara etimologis berarti alat tidak langsung untuk mencapai tujuan.Keberhasilan serta kelancaran dalam kegiatan alih media arsip pasti memerlukan sarana dan prasarana yang handal dan sesuai standar kearsipan. Adapun sarana dan prasarana yang dibutuhkan antara lain: 1) penyediaan ruang, 2) peralatan, 3) perangkat lunak,4) kualifikasi arsip dan kualifikasi sumber daya manusia (Effendhie, 2010).

Hasil penelitian menunjukkan bahwa SMK Negeri 4 Gorontalo memiliki perangkat komputer, jaringan, print dan scanner. Sarana prasarana yang sudah sesuai standar untuk penerapan kearsipan berbasis digital, namun masih membutuhkan tambahan sarana prasarana lainnya agar lebih memadai untuk mendukung penerapan kearsipan berbasis digital.

\section{Pendanaan}

Pendanaan pada konteks ini adalah berorientasi pada biaya penyelenggaraan dan pengelolaan pendidikan. Indikator mengenai hal ini berada pada kategori kurang siap dengan nilai persentase yang diperoleh yaitu $75.13 \%$. hal ini pendanaan yang ada di sekolah hanya bersumber dari pendaan tunngal yaitu dana BOS. Biaya pendidikan merupakan salah satu komponen intrumental (instrumental input) yang sangat penting dalam penyelenggaraan pendidikan disekolah (Supriyadi, 2001:3). Menurut (Soetjipto, 1992:76) pengelolaan keuangan meliputi kegiatan perencanaan, penggunaan atau pemanfaatan, pencatatan data, pelaporan dan pertanggungjawaban yang dialokasikan untuk menyelenggarakan sekolahdengan tujuan untuk menunjukkan tertib administrasi keuangan sehingga pengurannya dapatdipertanggungjawabkan sesuai dengan ketentuan yang berlaku. Pembiayaan pendidikan meliputi pada tiga hal : 1) biaya satuan pendidikan, 2) biaya pengenggaraan dan pengelolaan pendidikan, dan 3) biaya pribadi peserta didik (Masditou 2017:193).

Hasil penelitian di SMK Negeri4 Gorontalo mengenai pendanaan hanya bersumber dari pendaan tunngal yaitu dana BOS. pendanaan yang terbatas merupakan salah satu faktor penghambat efektifitas dalam pengelolaan pendidikan serta pada penerapan program kearsipan berbasis digital. 


\section{SIMPULAN}

Berdasarkan hasil penelitian dan pembahasan maka dapat disimpulkan: Kebijakan sekolah mengenai penerapan kearsipan berbasis digital di SMK Negeri 4 Gorontalo berada pada kategori siap. Prosedur penerapan kearsipan berbasis digital di SMK Negeri 4 Gorontalo berada pada kategori siap. Kesiapan sumber daya manusia dalam penerapan kearsipan berbasis digital di SMK Negeri 4 Gorontalo berada pada kategori siap. Kesiapan sarana dan prasarana dalam penerapan kearsipan berbasis digital di SMK Negeri 4 Gorontalo berada pada kategori siap. Pendanaan dalam penerapan kearsipan berbasis digital di SMK Negeri 4 Gorontalo berada pada kategori kurang siap.

\section{REFERENSI}

Arikunto, Suharsimi. 2006. Prosedur Penelitian Suatu Pendekatan Praktek. Jakarta: PT Rineka Cipta.

Depdikbud. 2002. Kamus Besar Bahasa Indonesia. Jakarta: Balai Pustaka.

Effendhie, Machmoed. 2008. Arsip Dan Arsiparis Indonesia (Sebuah Catatan Kecil) Buletin Kearsipan "Khazanah”.Volume I No.1 Yogyakarta: Arsip UGM.

Ismail, A. \&Jamaludin. 2009. "Towards establishing a framework for managing trusted records in theelectronic environment" in Records Management Journal,15(3)131175.

Masditou. 2017. Manajemen Pembiayaan Pendidikan Menuju pendidikan Yang Bermutu. Jurnal ANSIRU PAI Vol. 1 No.2.

Muhidin,dkk.2016.PengelolaanArsip Digital. Jurnal: Pendidikan Bisnis dan Manajemen,Volume 2, Nomor 3, November2016, Halaman 187-183.

Muhidin, S. A dan Hendri Winata. 2016. Manajemen Kearsipan Untuk Organisasi Publik, Bisnis, Sosial, Politik, danKemasyarakatan. Bandung: CV. Pustaka Setia.

Soetjipto. 1992. Administrasi Pendidikan. Jakarta.

Sugiyono. 2002. Statistik Untuk Penelitian. VI. Bandung: Alfabeta.

Sukoco, Munir Badri. 2007. Manajemen Administrasi Perkantoran Modern. Jakarta: Erlangga.

Supriyadi, D. 2001. Satuan Biaya Pendidikan Dasar dan Menengah. Bandung: Remaja Rosda Karya.

Syagala, Syaiful. 2008. Administrasi Pendidikan Kontemporer. Bandung:Alfabeta

Widodo, Joko M.S. 2013 Analisis Kebijakan Publik (Konsep dan Aplikasi Analisis Kebijakan Publik). Malang: Bayumedia Publishing. 